\title{
Development Model Islamic Education of Basic and Intermediete Level Pesantren Based (Islamic Boarding School)
}

\author{
Mohamad Erihadiana, Jaja Jahari \\ UIN Sunan Gunung Djati \\ Bandung, Indonesia \\ erihadiana@uinsgd.ac.id
}

\begin{abstract}
This study tries to describe the integrated school education model developed at this time. Through this research can be designed and developed the pesantren (boarding school) as a renewal of modern pesantren education system. This study used a qualitative approach naturalistic with descriptive method. The descriptive naturalistic methods used in this study is due to the problems being considered regarding current natural problems at this time, can be observed and analyzed to get the meaning contained therein. Descriptive method is used because it can describe the real situation that is happening at this time, it can also provide a clearer, systematic, factual, and accurate general description related to the information of the phenomenon under study. The findings and analysis of the results of these studies cover four aspects: (1) The purpose of boarding educational institutions; (2) the educational process in boarding school; (3) the advantages and disadvantages of the boarding education system; and (4) the graduates. The aim of the boarding school system in Islamic education are: produce student's intelligence, pious, has the soul of a leader. The education model that combines school with pesantren (known as a boarding school) that is development a school system that is combined with boarding schools in primary and secondary education levels.
\end{abstract}

Keywords—boarding school; islamic education; pesantren

\section{INTRODUCTION}

Pesantren is an institution that has been widely known since centuries ago, representing education characterized by Islam with various peculiarities both on educational goals, curriculum, learning systems, and learning methods. Pondok Pesantren is a religious institution that provides education and teaching as well as developing and spreading the science of Islam. The term huts in Indonesian pesantren, especially the island of Java, is more similar to lodge in the neighborhood hermitage, which is a simple housing arranged in the form of rooms that are boarding for santri. While the term pesantren etymologically the origin of the santri which means place students. Students or santri study the religion to a kyai or shaykh lived pesantren [1].

Pesantren as the model of the first Islamic educational institution that supports the continuity of the national education system. Pesantren so far no doubt its contribution in order to educate the nation's life as well as to produce intellectual cadres who are ready to appreciate their scientific potential in society [2].

The actual development of pesantren today is a change of attitude that occurs in pesantren society. Currently pesantren tend to adapt to the influence of modernization, especially in the field of education. The emergence of madrassas/ schools from elementary school as far as university in pesantren environments is a phenomenon that has developed over the decades. In addition, what is interesting to note is the emerge of an educational model that combines schools with boarding schools (known as boarding school).

Boarding based School is an educational model by developing a school system combined with pesantren both at the primary and secondary education level, especially Junior High School (SMP/ MTs) and Senior High School (SMA/ MA) to achieve excellence both in the academic aspect, nonacademic, personality, firm and steady in the child.

This research tries to describe the integrated school education model that is developing at this time. Through this research can be designed and developed a model of boarding school based education as a renewal of pesantren education system.

\section{UndERSTANDING OF PESANTREN}

Pesantren is a traditional Islamic educational institution to study, understand, deepen, live and practice the teachings of Islam by emphasizing the importance of religious morality as a guideline of everyday behavior [3].

Pesantren itself according to the basic understanding is the place to study the santri, while the cottage means a house or a simple residence made of bamboo. Besides the word "cabin" may also come from the Arabic word "punduq" which means hotel or hostel [4].

There are several opinions about the origin of the word pesantren. Prof. Jhon argues that the word pesantren comes from the word terma "santri" from tamil language which means teacher reciter. In another opinion like said C.C Berg, term santri derived from the Indian word "shastri" which means people who know holy books. But according to Robinson, the 
word santri comes from the word Tamil "sattiri" which means people living in a poor house or religious buildings in general [5].

Pondok Pesantren is a religious institution that provides education and teaching as well as developing and spreading the Islamic sciences. The term huts in Indonesian pesantren, especially the island of Java, is more similar to lodge in the neighborhood hermitage, which is a simple housing arranged in the form of rooms that are santri's home stay. While the term pesantren is etymologically is place of the students to study the religion from a kyai or shaykh at boarding [1].

Steenbrink describes the state of life in the boarding school as follows [6]:

"To absorb the soul of Islam, pesantren is not only respected as a place of learning, but more emphasized as a place of residence which is fully filled and impregnated with religious values. There is no other place where prayer is established with obedience. At the daytime, everywhere people can hear the santri recite the Qur'an with a beautiful, the correct reading with correct tajwid, at night also can be found the atmosphere of people reading the Qur'an and establishing prayers in the silence of night ".

According to Abdurrahman Mas'ud there are several main characteristics of pesantren culture among them are:

- Modeling. In the history of Islam can be identified with Uswatun Hasanah or Sunnah Hasanah is an ideal example that should or should be followed in this community. Not deviating from the basic teachings of Islam, modeling in the world of pesantren seems more interpreted as Tasyabbuh. Modeling following a leader's tokong is an important part of Javanese philosophy. Walisongo who became the direction of the santri course oriented to the great teachers and Muslim leaders. Prophet Muhammad SAW. The strength of modeling is supported and in line with Java's value system that emphasizes paternalism and patron-client relations that are already rooted in Javanese culture. Like the teachings of Islam that is exhibited with wayang media at once is an easy model in the example. Modeling in the world of pesantren is not limited to one dimension of life.

- Cultural Resistance. The idea of cultural resistance coloring the intellectual life of the pesantren world. Subjects taught in this institution through the guidance and blessings of a kyai as the main teacher or Irsyadu Ustadzin classic book or yellow book, in though and transmit from one generation to the next, which also shows ease of kyai leadership. The content of the teaching of the yellow scriptures offers the continuity of true traditions, al Qadim al-Shalih who maintained the religious sciences from the time of the classical and the middle age.

- High scientific culture. The world of pesantren is identical with the world of science. The ideal reference of scholarship of the pesantren world is sufficiently conflated to include the core of the basic teachings of
Islam itself sourced from Al Qur'an Hadist. Major figures of classical times such as Imam Bukhari as well as the oral tradition that developed always glorify the great of Javanese scholar such as Nawawi al Bantani, Mahfudz al-Tirmisi and others. Full day-long education in pesantren world with relative time limit, as well as teacher relationship with unstoppable students is the implementation of Prophet's teachings that emphasizes the necessity of seeking knowledge from infant to death, min-al mahdi ila al-lahdi [7].

- Pesantren is an educational institution that has its own characteristics in its components, such as According to Zamaksyari Dhofier the five basic elements of pesantren tradition is there are huts, mosques, students, classical Islamic books, and kyai [8]. According to experts, an educational institution can be called a pesantren if it has essential requirements. The requirements of the pesantren itself are: There is a kyai; there are santri; there is a cottage; there is a mosque; there is the teaching of the yellow book [9].

\section{BOARDING SCHOOL}

Boarding school consists of two words: boarding and school, boarding means boarding and school means school. Boarding school is a boarding school system, students and or teachers and school managers live in dormitories within the school for a certain period of time.

Actually the term Boarding School is not something new in the context of education in Indonesia. Because for a long time the educational institutions in Indonesia presented the concept of education Boarding School which is named "Pondok Pesantren". It can be said that pesantren besides developing into modern pesantren also developed into boarding school or boarding school [10].

The development of pesantren into boarding school is in line with the development and changes in the form of boarding school. Minister of Religious Affairs of the Republic of Indonesia issued a regulation, number 3 of 1979, which classifies pesantren as follows:

- Type A, i.e. where the santri learn and live in boarding school dormitory pesantren with teaching that takes place traditionally (wetonan or sorogan system).

- Type B, which organizes classical teaching, and instruction by kyai is application, given at certain times. Students live in boarding school dormitories.

- Type C, i.e. boarding school is only a dormitory, while the santrinya learn outside (madrasah or public schools) kyai just supervise and as a coach of the santri.

- Type D, which is organizing the system of boarding school and school system or madrasah [10].

\section{RESEARCH METHODS}

This research uses qualitative naturalistic approach using descriptive method. Naturalistic descriptive method is used in this research because the problem that is studied concerning the 
problem which is going on naturally nowadays, can be observed and analyzed to get the meaning contained in it. Descriptive method is used because it can describe the actual situation occurring at this time, also can get a clearer picture, systematic, factual, and accurate which related to phenomenon studied.

In general, the nature of all forms of descriptive inquiry is to describe and interpret existing data, for example about the situation experienced, a relationship, activities, views, attitudes, visible or an ongoing process, ongoing influence, emerging abnormalities, emerging tendencies or tapered contradictions and so on [11].

Research subjects in this study were teachers and students as well as other respondents required at the Boarding School of al-Aqsa and MTs (Boarding School) ar-Raudhah Kabupaten Bandung; and SMA (Boarding School) Nurul Fikri West Bandung Regency. Research subjects determined through interviews and direct observation, which concerns the objectives, materials, methods, sources, and media, and the form of evaluation of Islamic education conducted.

Data collection techniques in this study were conducted through three ways, namely: observation, interview, and documentation study.

\section{RESULTS AND DISCUSSION}

\section{A. Conditions of MTs. Ar-Raudloh}

The idea of establishing the Ar-Raudloh MTs began of existence Pancasila Mosque. Pancasila Mosque is located beside KUA Cileunyi and Padaleunyi toll road, precisely at Jalan Galumpit RT / RW: 01/16, Cileunyi Kulon Village, Cileunyi District, Bandung Regency. The mosque is called Jamie Ar-Raudloh mosque. This mosque is large enough and the condition is still good. The mosque was founded on the services of Yayasan Pendidikan Islam Al-Hasan (YPI AlHasan) founded by a married couple, namely: KH. Kanta Sumpena, SH (deceased) and $\mathrm{Hj}$. Nyanyu Maryam KS (deceased) when he ( $\mathrm{Hj}$ Nyanyu Maryam KS) became a member of the MPR RI during the New Order era. After the founder of the Al-Hasan Islamic Education Foundation (YPI Al-Hasan) passed away (KH Kanta Sumpena, SH in 2000 and Hj Nyanyu Maryam KS in 2002), the foundation is managed by his daughter's son, led by his eldest son, Drs. H. A. M. Ruslan who had become the chairman of West Java parliament period (2004-2009), journalist of Pikiran Rakyat Daily, and he became chairman of KONI West Java.

Activities in the mosque Jamie Ar-Raudloh is more widely used by jema'ah outside study and the Group of Hajj Guidance (KBIH) Ar-Raudloh. Unfortunately, the surrounding community lacks a sense of belonging to this mosque, as evidenced by the lack of enthusiasm of the surrounding community on the activities of the Jamie Ar-Raudloh mosque and only a small share among those who come for both congregational prayers and Jum'ah prayers. In fact, sometimes the mosque is locked, due to lonely activities conducted by the public in the mosque.
This fact is because when the mosque was founded, it did not involve the participation of the surrounding community, only a small part participated, and usually, if the mosque was established without involving the local community, the community lacked the sense of ownership that resulted the mosque have not prosperous.

On that basis, the motivation of the Al-Hasan Islamic Education Foundation (YPI Al-Hasan) to establish an educational institution that among the objectives of the implementation of education, in addition to realizing the National Education Goal also in order to involve the participation of surrounding communities in prospering the mosque. To realize that motivation, the foundation held a deliberation with local community leaders and local government. From the results of these deliberations, came the idea which was then agreed to establish Madrasah Tsanawiyah with its management handed over to community leaders around.

Therefore, in 1999, the Ar-Raudloh Integrated Tsanawiyah Madrasah was established. Because one of the motives of the establishment of Madrasah Tsanawiyah is to prosper the mosque, the education system used in this madrasah is designed so that students can prosper the mosque. Therefore, the students of Madrasah Tsanawiyah Integrated Ar-Raudloh are required to stay in the madrasah (boarding school) madrasah) for 24 hours. With the large amount of time that the madrasah provides for students, the curriculum of Madrasah Tsanawiyah presented by the Ministry of Religious Affairs was developed with the local curriculum of the Ar-Raudloh Integrated Tsanawiyah School. Since the founding year (1999 AD), the people's attention to the Ar-Raudloh Integrated Tsanawiyah Madrasah is higher, this can be evidenced by the growing number of pupils from year to year in quantitative terms [12].

In the implementation of education in Tsanawiyah Madrasah Ar-Raudloh, so that for teachers succeed in carrying out their teacher's duties should be assisted by staff, because the staff is the one who technically organizes all kinds of educational implementation. On average, they succeeded in educating their students, one of the indicators is in the high KKM (Working Group Madrasah) Cikancung, this madrasah ranked number 2 National Examination results. Viewed from the aspect of morals, generally the students experience improved morals in a better direction.

At relatively young age, The Integrated Tsanawiyah madrasah Ar-Raudloh, has a large number of pupils have a study group consisting of 2 (two) class for class VII; 2 (two) class for class VIII; and two class for class IX, with an average of 35 pupils.

The Integrated Tsanawiyah madrasah Ar-Raudloh has the means of learning (in the sense of hardware) that can be considered adequate (in the size of a new madrassa in the maize). The learning facilities are endowments and grants from Yayasan Pendidikan Islam (YPI) Al-Hasan which is entirely submitted to the madrasah management to be utilized and functioned properly. And operationally, according to the Head of Madrasah this learning tool has been functioned and utilized with the best. 


\section{B. Condition of SMP Plus Al Aqsha Jatinangor}

Starting from a regular teach religious that was cared for by K.H. Hasan Abdullah Muhyi, Junior High School Al-Aqsa Modern, originally named Madrasa Hasan Mustofa, because of K.H. Hasan Mustofa, who is the best known cleric in Cibeusi, and he was also the one who bought the land the where the madrasah is located.

Along with the passage of time, Al-Aqsa is now under the Foundation Eleven, the foundation belongs to the Cibeusi family. The name of Al-Aqsa is given by Drs. Mukhlis Aliyudin, M.Ag who is the son of K.H. Hasan Abdullah Muhyi. As an alumnus of Pondok Modern Darussalam Gontor, he wanted to combine the educational tradition already in AlAqsa with an educational model that he felt during his studies in Darussalam. Of course this is not easy. Challenges from various circles, external and internal even adorn the struggle heavily Drs. Mukhlis to realize his strong desire. Alhamdulillah, thanks to unending prayer, unyielding spirit and steel determination, Al-Aqsa is now a modern cottage that should be counted as one of the junior high school famous in Jatinangor.

Junior Secondary Education Plus Al Aqsa Jatinangor is equivalent to Junior High School which substantially consists of two education systems namely SMP and Kuliyatul Muallimin wal Mu'allimat al Islamiyah (KMMI). SMP Plus Al Aqsha teaches two areas of science, namely general science and religious science.

\section{Condition of SMA Nurul Fikri}

In January 2007, began to form the foundation which will become the umbrella of pesantren. So from then on have begun the construction of the building for the laying of the first stone was done by the Governor of West Java, Mr. Ahmad Heryawan. The construction of the building is done at RT 04/04 Kampung Cidadap, Cibodas Village, Lembang District, West Bandung-West regency.

Pesantren Madani Islamic Education first stands receiving 8 classes consisting of 4 classes of junior high school and 4 high school level. The number of first admissions for junior high school received 77 students consisting of 50 santri sons and 27 santri daughter, and for high school level received 83 students consisting of 54 santri son and 29 santri daughter. Total students at the first year of admission for junior and senior high school is a total of 160 santri. The teachers who will handle the santri numbering 160 is 45 teachers who come from various universities, both within and outside the country. As an illustration, the existing teachers consist of 22 people with general education background and 28 people with religious education background. The number of administrative personnel amounted to 4 people while non-educational personnel amounted to 12 people.

Based on the results of research in two elementary schools namely MTs. Ar-Raudhah Cileunyi and Junior Plus Al-Aqsa Jatinangor and one high school level that is SMA Nurul Fikri Lembang there are several findings.

The findings of the study include the following: (1) The objective of the educational institution; (2) educational process;
(3) the advantages and disadvantages of the education system; and (4) results of graduate.

\section{Objective of Education}

The objective of pesantren education is to create and develop the Muslim personality, that is the personality of the faithful and devoted to God, the noble character, beneficial to the society or to the community by way of becoming a community servant or servant like the Apostle i.e. serving the community as the personality of the Prophet Muhammad The Prophet), able to stand alone, free and firm in personality, spread religion or uphold Islam and the glory of Muslims in the midst of society (Izzul Islam wal Muslimin), and love science in order to develop the personality of Indonesia [3].

According to Zamaksyari Dhofier says the purpose of education is not solely to enrich the mind of the disciple with explanations, but to elevate morale, to train and heighten the spirit, to appreciate spiritual values and humanity, to teach honest and moral attitudes and behavior, and prepare the disciples for live a simple and clean heart [8]. The purpose of pesantren education is not to teach the interests of power, money and worldly majesty but instilled in them that learning is solely a duty and devotion to God.

The objective of pesantren education according to Arifin quoted by Mansur there are two general goals and special goals [13]. The general purpose of pesantren education is to guide the students (santri) to become human beings with a religious personality with his religious knowledge he is able to become Islamic preachers in the surrounding community through knowledge and charity. While the goal is especially to prepare students to become pious and deepen the knowledge of religion that is taught kyai concerned and practice in society.

From the various aims of pesantren education above it can be concluded that the purpose of Islamic Boarding School is the same as the focus of the pesantren education aim is to empower santri, worldly oriented and ukhrowi to realize ubudiyah to Allah SWT in human life both individual and society.

It's just that the Islamic Boarding School's goal of the development of the global era, the development of science and technology, the changes, and the events occurring in society, and the hope of the future world community by always abiding by the aims of pesantren.

For educational objectives, curriculum, teaching methods, and educational model itself. In relation to curriculum issues, Hilda Taba in his book "Curriculum Development: Theory and Practice" is of the opinion that curriculum development should be rational and scientific in which the determination should be based on reality-based valid elements which are derived from tradition and culture, social demands, and community habits. Therefore, the scientific curriculum should refer to the analysis of society and culture, the study of learners and the learning process, as well as the specific characteristics of the building of a particular epistemology of science in order to determine the institutional objectives and the characteristics of the curriculum. 
More important than that is the reinforcement of cultural and religious values so that the subjects did not fall in the hedonic culture, materialistic and all the glamor of the west as a system of life and behave. In his application he should always pay attention to the principles of psychology, psychometrics, and pedagogy. All learning activities should be based on the purpose of achieving developmental tasks and learning principles that include matters related to cognitive, affective, individual uniqueness, motivation, talent, and inclination, and interpersonal relationships. All of that will then affect instructional patterns and models, classroom management, assessment of learning outcomes, management of learning media and so on.

\section{E. Education Process}

The process of education in pesantren can be seen from the curriculum. According to Arien Lary cited by Fathurrahman the curriculum, in short, means an activity that includes detailed student activity plans (santri), including educational materials, infrastructure, learning strategies, program arrangements to be applicable, and those that include activities aimed at achieving desired targets and goals [14].

The curriculum in pesantren is based on the level of ease and complexity of science or issues discussed in the book, so there is a beginning, intermediate and advanced level. The type of pesantren education is non-formal, only studying religion, based on the classical books covering the subjects of study: tauhid, tafsir, hadith, fiqih, ushul fiqih, tasawuf, arabic (nahwu, sharaf, balaghah, and tajwid), mantik, and morals. Each field of study has an easy level of complexity of each discussion. Accordingly, evaluation of learning progress in pesantren is also different from evaluation of madrasah and public schools [3].

But the learning process at Islamic Boarding School is based on the assumption of closeness between students / teachers and teachers in boarding school created by sufficient intensity of meetings that will facilitate the transfer of knowledge from educators to learners. Proximity will change the teacher's position in the eyes of the students. From the figure feared or respected to the figure who want to emulate. Personal example can build confidence to communicate internally personal. Then it will be created without the child feel alien to the ability they have in conveying the message or ideas of his thoughts to others. Whether it is in verbal or nonverbal forms, such as determining their daily attitudes and behaviors.

Their exemplary, sincere, congruence, and preparedness of the day-to-day teachers will empower and inspire students / students to free up their potential as learners. It will accelerate the growth of his emotional intelligence. In this case the theory that a pesantren should exist kyai still remain with the record of all teachers is kyai.

According to Lazanov, if the learning method is maximally empowered, then the success of the students will be easier to realize. Achievement can be done if there is always an interaction that stimulates the growth of mental attitude. But for that required a quantum teacher who has good communication skills. Coupled with an effective teaching design, the harmonization of both will provide a dynamic learning experience for students/ santri.

\section{F. Advantages and Disadvantages of Boarding School Based Education System}

The advantages of the Islamic Boarding School system are aspects of integration between Religion and science. Implications for Islamic Education is a broader and more innovative strategy of Islamic learning. These strategies include integration or internalization of religious values into general learning materials. Integration or internalization of religious values into the general learning materials is the concept of developing Islamic religious education in schools, by making religious education oriented towards improving the quality of faith and piety to God Almighty as the core development of education in schools, especially to anticipate the moral crisis or akhlak [15].

In addition, through Islamic Boarding School can be developed strategies such as: (1) optimization of Islamic Religious Education; (2) the creation of a school environment climate conducive to the growth of faith and piety; (3) extracurricular activities that growth faith and piety; (4) strengthening school cooperation with parents and community in the development of faith and piety.

Through these strategies, it is hoped that collaboration between teachers, students, school environment, parents, and community will be achieved as a concerted effort to achieve the educational objectives in accordance with the mandate of the National Education System Law which is aimed at the development of the potential of learners to become human beings who believe and fear Allah God Almighty, have a noble character, healthy, knowledgeable, capable, creative, independent, and become a citizen of democratic and responsible (Act Sisdiknas Chapter II Article 3 Year 2003).

Through collaborative efforts there will be integration of religious values into learning. Through collaborative learning model, Islamic Education is designed a collaborative effort that aims to cultivate religious values through learning in schools as a foundation in facing global living conditions, also seeks to have students who have strong spiritual powers of faith, and practice religious practices as the way closer to Allah Almighty. In the end, it is expected that moral values can grow and manifest in everyday life and formed healthy souls who are ready to face the challenges of life by having a strong creed (al'aqîdah al-salîmah), good worship (al-'ibâdah al-shahîhah), and noble character (al-akhlâq al-karîmah).

While the disadvantages are high school financing is high enough to be less accessible by nearby communities. The burden of learning to be followed by learners from the entire program is quite high. Schools are organizational lack of school relationships with parents. In addition, the human resources of educators and educators have a heavy burden and high responsibility amid their time limitations.

\section{G. Results of the Boarding School Graduates}

The curriculum developed at the Boarding School is an integrated curriculum. The curriculum consists of national 
curriculum and boarding school. So the average student is able to master some aspects of Islamic knowledge such as: Aqidah, Tafsir and Ulumul Qur'an, Hadith and Ulumul Hadist, Arabic Language, Sirah Nabawiyah, Fiqh, Tahsin and Tahfidz.

Students of Islamic Boarding School are not only able to compete in academic achievement, but have more ability with the ability of two foreign languages namely English and Arabic, able to memorize maximum 30 juz or at least have memorize between 1-6 juz. The results of graduates of Islamic Boarding School are in line with the educational theory proposed by W. Huitt in Moral and Character Development, cites Walsh's view, which states that education is the process of preparing the younger generation for social inheritance, therefore education must include three dimensions: (1) developing knowledge; (2) training mental endurance; and (3) build character. Spiritual values are part of the mental process associated with religious beliefs that psychologists recognize are of paramount importance in life.

The Islamic Boarding School shows that Islamic Education is not centered on the knowledge (cognitive) aspect but the pillars of education should include four principles are: learning to know, learning to do, learning to be, and learning to live together.

\section{CONCLUSION}

School-based Pesantren or Islamic Boarding School highly emphasize the pattern of integrated education in the formation of santri characters. The goals to be achieved from the boarding school system in Islamic education are:

- Produce a smart student profile visible from academic, linguistic and alqur'an style. Intelligence is needed by every human being to develop themselves in life. Produce the profile of a pious disciple is a good person where kindness will bring blessing and facilitate the steps to achieve success. Achievement will lead to the good of both world and the hereafter. From this good self that will be able to easily fix others. Able to produce students who have a leader's soul, or repair others. Being able to lead can be seen from the aspect of self-reliance, pioneer and caring.
- The emerge of an education model that combines schools with pesantren (known as boarding school) is an educational model by developing a school system combined with pesantren both at the primary and secondary education level, especially Junior High School (SMP/MTs) and Senior High School (SMA/MA) to achieve excellence both in the academic aspect, non-academic, and personal strong, firm and steady in the child.

\section{REFERENCES}

[1] M.R. Nasir, Finding Typology Ideal Education Format: Pondok Pesantren in the Middle of the Flow of Change. Yogyakarta: Student Literature, 2005.

[2] I. Tolkhah, and A. Barizi, Opening the Education Window-Unraveling the Tradition Roots. Jakarta: RajaGrafindo Persada, 2004.

[3] Mastuhu., Dynamics of Pesantren Education System: A Study on the Elements and Value of Pesantren Education System. Jakarta: INIS, 1994.

[4] G.R. Terry, and L. Hasbullah, Kapita Selekta Islamic Education. Bandung: PT. Youth Rosdakarya, 1996.

[5] M.A. Hasyim et al., Initiating Future Pesntren: Sewerage for New Indonesia. Yogyakarta: Publisher Qirtas, 2003.

[6] K.A. Stenbrink, Pesantren, Madrasah, and School. Jakarta: LP3ES, 1994.

[7] S.M. Ismail, et al., Dynamics of Pesantren and Madrasah. Yogyakarta: Student Literature, 2002.

[8] Z. Dhofier, Tradition of Pesantren. Jakarta, 1994

[9] A. Tafsir, et al., The horizon of Islamic Education Thought. Bandung: Pulpit Pustaka, 2004.

[10] M. Noor, Portrait of Pesantren World. Bandung: Humanities, 2006

[11] Koentjaraningrat, Introduction to Anthropology. Jakarta: PT. Rineka Cipta, 1990

[12] A. Azra. Islamic Education: Tradition and Modernization Towards the New Millennium. Jakarta: PT. Logos, 1999.

[13] Mansur, Morality of Pesantren: Gulping the Wisdom of Lake Life. Yogyakarta: Safiria Insania Press, 2004.

[14] P. Fathurahman, The Advantages of Pesantren Education: The Alternative of Integrated Education System of the XXI Century. Bandung: Tunas Nusantara, 2000.

[15] Muhaimin, Development of Religious Curriculum in Schools, Madrasahs, and Universities. Jakarta: RajaGrafindo Persada, 2005. 